DOI: 10.1515/auseur-2016-0004

\title{
English and the Brain Drain: an Uncertain Relationship
}

\author{
Christopher HOUTKAMP \\ University of Amsterdam \\ c.houtkamp@uva.nl
}

\begin{abstract}
In his book Linguistic Justice for Europe and the World, Van Parijs analyses in one of his chapters the brain drain from non-Anglophone to Anglophone countries, which hurts the economic development of the nonAnglophone states. Van Parijs deems it clear that English is a very important factor to explain high-skilled migration. He, therefore, urges the nonAnglophone countries to relax their linguistic territorial constraints and allow English as a communication language in many different sectors, most notably higher education and scientific research. This would remove the incentive for potential expatriate brains to migrate for linguistic reasons. This article takes a closer look at Van Parijs' reasoning and proposed solutions. It is concluded that the assumed connection between English and high-skilled migration cannot be proven empirically for research on this topic is scarcely available. Furthermore, the solutions presented by Van Parijs will produce uncertain results at best. Van Parijs rightfully puts the brain drain problem on the political and research agenda, but much more additional studies are needed to formulate solid solutions.
\end{abstract}

Keywords: brain drain, English, high-skilled migration, expats, language and migration

\section{Introduction}

In his book Linguistic Justice for Europe and the World, Philippe van Parijs argues extensively in favour of embracing English as a lingua franca and of using it as a means to combat global injustice. One of his many arguments is that a more liberal, pro-English language regime in non-Anglophone countries could help combat the exodus of high-skilled migrants towards the English-speaking worlds. This is an interesting argument in the context of migration research for it assumes a clear connection between 'language' and 'migration'.

The body of theoretical work on explaining migration is rather expansive, too expansive to be discussed here in depth. Some of the more dominant theories 
seek to explain it through e.g. economic differences (Sjaastad 1962, Todaro and Maruszko 1987, Borjas 1989), the presence of social networks in the country of destination (Stahl 1993), and psychological factors (i.e. status enhancement) (De Jong-Fawcett 1981). These explanations are naturally not mutually exclusive: for instance, economic as well as psychological factors can play a role when explaining one's migration. These theories have been empirically tested in different contexts. In addition to these established theories, migration is also sometimes explained through other, more recently introduced factors, such as climate change, public attitudes toward migrants in the country of destination (Doomernik-Koslowski-Thränhardt 2009), and - particularly important in the case of high-skilled migration - the presence of a policy framework to attract expatriate brains (i.e. green-card- of blue-card-type initiatives). It may have become clear that one factor has been missing until now in this summing-up of factors, namely 'language'. Language is compared to the other mentioned explanations severely understudied in migration research. It is sometimes considered as an auxiliary factor, for instance when analysing migration from former colonies to their former colonial 'motherland', but it is rarely considered separately.

Van Parijs' emphasis on the role of language to explain migration is thus quite exceptional in the current field of migration studies. In this contribution, I will briefly discuss his argument and its merits.

\section{English, Linguistic Territoriality, and the Brain Drain}

In his chapter on 'linguistic territoriality', Van Parijs analyses several downsides of the linguistic territoriality principle (i.e. the idea that linguistic rights should be defined based on territory). One of these downsides is the asymmetric flow of human capital towards the so-called 'ground floor' of the world. The ground floor are those countries where English is the dominant language, i.e. 'the greater part of North America, the British Isles, Australia, and New Zealand' (Van Parijs 2011: 159). Van Parijs lists several facts to back up his argument: $75 \%$ of the world's expatriate brains, which are defined as graduates of tertiary education who do not live in their country of birth, are based in just three ground-floor countries (the U.S., Canada, and Great Britain). In 2000, there was a surplus of 12 million brains in the OECD regions. In other words: the sum of high-skilled immigration and emigration nets a positive result of 12 million for the OECD regions. Even within the OECD, the English-speaking countries are the largest beneficiaries of high-skilled migration. The six Anglophone OECD countries alone had a surplus of 14 million brains, with 10 million residing in the USA, whilst the non-English OECD states suffered a net loss of 2 million brains. In other words: looking at these statistics, it is evident that the English-speaking part of the world is an 
incredible magnet for high-skilled migration. The result is a tremendous brain drain from the non-English towards the English-speaking world, a development that can perpetuate global inequality.

Van Parijs acknowledges that there are many factors to explain this brain drain, but he claims that 'It would be hard to deny the importance of the linguistic factor' (Van Parijs 2011: 160). According to him, migrants, especially high-skilled migrants, are more likely to move to countries where they can be well-informed of the job opportunities and where their children can learn a language that is widely used in the world. It is obvious that many migrants opt for an English-speaking destination. Van Parijs describes the likely future migration trend as follows:

In a world in which English is being snowballed, through the mechanism sketched at the start (1.3-1.5), into the single global lingua franca, we can expect the formation of a huge ground floor towards which the highly skilled of India and China, Finland and Hungary, Germany and France will tend to converge more and more, without anything like a matching tendency for the highly skilled of the United States or Britain to climb up to the Mandarin plateau, let alone to the Hungarian peak (Van Parijs 2011: 161).

To (partly) prevent large-scale high-skilled emigration, Van Parijs urges the upper-floor territories to reconsider their language policies and relax the linguistic territoriality principle. By refusing to allow some use of English within their linguistic territories, he argues, they might be shooting themselves in their own foot. He is convinced that the exodus of their high-skilled citizens towards the ground floor would then continue and the upper-floor states will perpetually be set behind in the current knowledge-based economy. Even though the future for the upper floor looks rather bleak, Van Parijs does also point out several potential perks of high-skilled emigration which he calls 'diaspora buffers' (Van Parijs 2011: 162). Firstly, migrants often send resources back home, the so-called 'remittances'. Secondly, migrants can use the knowledge gained during their stay in the ground floor to help develop their countries of origin upon returning. Thirdly, the presence of foreign brains makes ground-floor information vulnerable to world-wide spreading, from which the upper floor can profit. Lastly, highskilled migrants, due to their presumed influence on the domestic politics of their country of destination, may have a potential positive influence on international development policies towards upper-floor countries.

As already briefly mentioned, Van Parijs calls for a relaxation of the territorial constraints on language to combat the brain drain. Especially in higher education and scientific research, students and staff should be allowed to do their work in English. Van Parijs also offers a policy solution to attract high-skilled migrants to the upper floor: the creation of - temporary - 'linguistically free zones' where 
the territorial constraints are lifted for a period of time regarding English. The people residing in these zones would be exempt of the heavy 'tax' of learning the local language and could confine themselves just to speaking English (Van Parijs 2011: 163).

\section{The Causes of Migration: the Role of Language}

As we have seen, Van Parijs attaches great importance to the linguistic factor in order to explain high-skilled migration. For an accurate assessment of his arguments' merits, it is important to consider whether these claims can withstand theoretical and empirical scrutiny. Thus, this section will compare the assumptions in Van Parijs' arguments with existing work in the field of migration and determine the strength of his claims.

The facts presented by Van Parijs regarding the excessive surplus of expatriate brains in the Anglophone world are thought-provoking. On a first glance, it is not surprising that these statistics lead him to his aforementioned conclusions. However, there are two potential main problems with his line of reasoning. The first problem is of a methodological nature. As most researchers will realize, correlation does not equal causation. The fact that many expats reside in Anglophone countries is not a sufficient argument to claim that English is an explaining factor. Additional research that specifically analyses the connection between English and high-skilled migration is limitedly available. So, even though it is not unreasonable to assume that English plays at least some role, we have scarce means to weigh its exact impact and we have no understanding as to how the 'English high-skilled migration' mechanism exactly works. One of the rare empirical studies conducted by Adsera and Pytlikova (2015) on the connection between language and migration may help us set a first step towards a fair evaluation of Van Parijs' claims. They used a dataset on immigration flows and stocks of foreigners in 30 OECD destination countries from 223 source countries, originating from the years 1980-2010. The dataset contains many linguistic indicators, including linguistic proximity (i.e. the degree of similarity between the migrant's mother tongue and the language spoken in the country of destination) and linguistic diversity. The research yielded several main results (Adsera-Pytlikova 2015). Firstly, fluency in the language of the country of destination facilitates the transfer of human capital, meaning that the opportunity costs for migrants are lower when moving to a country where they have a good command of the dominant language. Secondly, migrants prefer to move to a country with a low degree of linguistic diversity since then they would only need to learn one language to gain access to the country's facilities. Thirdly, migration seems to occur more between countries that are linguistically similar. 
Fourthly, linguistic proximity matters most for non-English speakers. It is more likely for a Francophone to migrate to France than it is for an Anglophone to migrate to an English-speaking country. Especially this last finding is interesting in the context of Van Parijs' arguments. The authors speculatively argue that due to the likely higher proficiency of the average migrant in English rather than in other languages the role of English as an explanans diminishes. However, there is more emigration from countries with higher levels of tertiary education to the Anglophone world (Adsera-Pytlikova 2015), which is in line with Van Parijs' observation.

Next to the methodological issue, there is a second main problem. It lies in Van Parijs' proposed solutions. As explained earlier, he wishes to combat the brain drain from upper to ground floor by relaxing the linguistic territoriality regimes of upper-floor countries (Van Parijs 2011). High-skilled emigration might be diminished by expanding the role of English in higher education and scientific research, whilst upper-floor high-skilled immigration can be stimulated by forming linguistically free zones where territorial constraints are temporarily lifted, meaning that expats are not burdened with having to learn the local language (ibidem). Similarly to the first problem discussed in the previous section, there are few empirical studies to verify or deny Van Parijs' claims. His solutions will at least raise some questions. Let us start by mentioning that the solutions offered would probably have a very large impact on the upper-floor societies as a whole. Ricento's edited volume on Language Policy $\&$ Political Economy contains several case studies that show how a larger role of English negatively impacts the distribution of wealth in developing countries (Ricento 2015). In general, more English means more opportunities for the local elite and less or equal opportunities for the big masses.

Proposals to relax the linguistic territoriality constraints should thus be very well thought out and based on empirically founded assumptions. It is doubtful whether the proposal to make more room for English in upper-floor scientific research and higher education fits these criteria. Criticism can be adequately summarized by posing the following almost rhetoric question: would a high-skilled migrant from Ivory Coast who values his/her career prefer to study at Oxford/Cambridge/Harvard/ Princeton or at the University of Science and Technology of Ivory Coast, even if the latter has introduced an all-English programme? The answer is most likely negative. It can even be argued that a bachelor programme at this new, rebranded 'Ivory Coast University' would in terms of language skills be a very good preparation to do a master's programme in the ground floor, hereby thus increasing rather than decreasing the high-skilled exodus. Furthermore, regarding the 'linguistic free zones' that are meant to attract high-skilled immigrants to the upper floor, it can be said that removing language constraints may reduce the barrier for these migrants to settle in, but it is most likely not sufficient to actually stimulate migration. In 
the current scenario, with a relatively large share of economic opportunities being in the ground floor and other OECD countries, one can wonder whether the expats would opt for going to the upper floor.

\section{Conclusion}

The connection between language as an explaining factor and migration is unjustly understudied in academic research. The fact that Van Parijs, as one of the few scholars, does see the importance of this connection deserves praise. He rightly points out that the enormous surplus of high-skilled migrants in the Anglophone world is a barrier to achieve global justice. It is a problem worth studying and one that begs for a solution. This article attempted to study Van Parijs' arguments and determine the merit of his claims.

The main problem in this whole matter is the limited availability of empirical research. The paper by Adsera and Pytlikova is a salutary exception. The discussion on language and high-skilled migration is therefore of a speculative nature. The causal mechanism of English and high-skilled migration cannot be proven, for instance, in a strict scientific sense, but - looking at the statistics presented by Van Parijs - it is not unreasonable to accept a great part of his interpretation of the data. The proposed solutions are, however, more problematic due to the high degree of uncertainty and the likely negative impact they have on upper-floor societies as a whole. Do the uncertain advantages outweigh the probable disadvantages?

The best way out of the impasse is more empirical research. Van Parijs' argument could be seen as the start of a new research agenda to unravel the connection between language and (high-skilled) migration. An important component of this research could focus on survey research about motivations to migrate. Why exactly do expats move to the ground floor and what specific role does language play in their choices? How important is language weighed against other motivations to migrate? What measures can be taken to incentivize the high-skilled migrants to stay in their country of origin or to move to an upperfloor country? In order to have some answers to these kinds of questions, we need to have a well-informed discussion on the brain drain. Until then, caution is advised when implementing solutions.

The research leading to these results has received funding from the European Union's Seventh Framework Programme (FP7/2007-2013) under Grant Agreement No 613344. 


\section{References}

BORJAS, G. 1989. Economic Theory and International Migration. International Migration Review 23(3): 457-485.

DE JONG, G.-FAWCETT, J. 1981. Motivations for Migration: An Assessment and a Value-Expectancy Research Model. In: DE JONG, G.-GARDNER, R. (eds), Migration Decision Making. Multidisciplinary Approaches to Microlevel Studies in Developed and Developing Countries. New York: Pergamon Press, 13-58.

DOOMERNIK, J.-KOSLOWSKI, R.-THRÄNDHARDT, D. 2009. The Battle for the Brains: Why Immigration Policy Is Not Enough to Attract the Highly Skilled. Brussels Forum Paper Series, 3-23.

RICENTO, T. (ed.). 2015. Language Policy \& Political Economy. New York: Oxford University Press.

SJAASTAD, L. 1962. The Costs and Returns of Human Migration. Journal of Political Economy 70(5): 80-93.

STAHL, C. 1993. Explaining International Migration. In: STAHL, C.-BALL, R.-INGLIS, C.-GUTMAN, P. (eds), Global Population Movements and their Implications for Australia, Canberra: Australian Government Publishing Services.

TODARO, M.-MARUSZKO, L. 1987. Illegal Migration and US Immigration Reform: a Conceptual Framework. Population and Development Review 13: 101-114.

VAN PARIJS, P. 2011. Linguistic Justice for Europe and the World. New York: Oxford University Press.

HOUTKAMP, C. 2014. Integrating Language in Theories on Long-distance Movement: Migration vs Mobility \& the Concept of Motility. A'dam Multiling 2014/1(1): 16-26.

ADSERA, A.-PYTLIKOVÁ, M. 2015. The Role of Language in Shaping International Migration. The Economic Journal 125: 49-81. 